\title{
OPTIMUM CARRYING CAPACITY FOR BISON IN THEODORE ROOSEVELT NATIONAL PARK
}

\author{
Clayton B. Marlow \\ Lynn R. Irby \\ Jack E. Norland \\ Montana State University \\ Bozeman
}

\section{Objectives}

This project was designed to determine the optimum population size for bison in the Theodore Roosevelt National Park (TRNP) by fulfilling the following objectives:

1. Delineate primary and secondary areas of bison use.

2. Determine net primary productivity for major range sites within primary and secondary use areas.

3. Determine the general seasonal food habits of bison in TRNP.

4. Determine range trends under present population density of bison and the maximum carrying capacity of primary use areas.

5. Integrate range trend and carrying capacity estimates with management priorities for bison on the TRNP.

\section{Methods}

Prinary and secondary use areas were defined by directly observing bison for several days each month. During observation periods (average was 8 hours) habitat usage, herd location, and activity were recorded. Marked animals (those with characteristic horn shapes) were used to identify specific groups or herds.

Fecal density transects were used to augment the direct observation data. The park was broken into the following physiognomic categories: grassed bottoms, prairie dog towns, river breaks, ridge-ravine, cottonwood bottoms, old river terraces, sagebrush bottoms, scoria hills, woody draws, upland breaks and upland grasslands. Belt transects of $500 \mathrm{~m} \mathrm{x} 2 \mathrm{~m}$ were randomly placed within each physiognomic category and all feces occurring within the transect were counted to obtain a density estimate.

The second objective is being met through: 1) formation of a plant community map from infra-red aerial photographs, and 2) forage production figures for those communities (Kjar 1982, SCS n.d.a., Whitman 1978). 
Fecal matter for microhistological analysis was collected twice monthly. This allowed the determination of seasonal bison diets. Bison intake during spring, summer and fall will be taken from existing literature (Peden et al. 1974). Winter intake will be determined through a lignin dilution technique conducted by the investigators. Seasonal dietary composition and intake combined with plant community herbage production estimates for primary use ranges will be used in the final calculation of bison carrying capacity for the park.

Permanent range condition/trend transects were established on primary use areas in August 1983. Baseline plant community composition was measured along each transect.

\section{Results}

Direct observations were completed in June 1983. By December 1983, over 5,000 lines of behavior and location data had been entered into the computer and thoroughly checked for completeness and accuracy. Data analysis is progressing on schedule. Field verification of infra-red air photos was conducted during July, August and September, 1983. The plant community map is now almost two-thirds complete. Final herbage production estimates are expected to be completed in late March, 1984.

Fecal transects were completed in September, 1983 and summarization of the results is shown in Figure 1. The pattern in this figure suggests that bison favor old river terraces, prairie dog towns, and upland grasslands over riparian and shrub dominated lowlands.

All fecal matter has been prepared for microhistological analysis. Identification of plant fragments for diet composition began in November, 1983. All material for lignin dilution has been collected and analysis is projected to begin in January, 1984.

Range condition/trend data has been summarized and will be incorporated as an appendix into the final report.

The graduate research assistant, Jack E. Norland, will present a paper entitled, "Grazing Behavior of Free-Roaming Bison in Theodore Roosevelt National Park", at the Annual Meeting of the Society for Range Management, February 14, 1984 in Rapid City, South Dakota.

Completion of the final report is slated for June $30,1984$.

\section{Literature Cited}

Kjar, Kathie. 1982. Unpublished PhD. thesis. North Dakota State University, Fargo, ND.

Peden, G. G., G. M. Van Dyne, R. W. Rice, and R. M. Housen. 1974. The trophic ecology of Bison bison L. on shortgrass plains. J. App. Ecol. 11:489-498. 


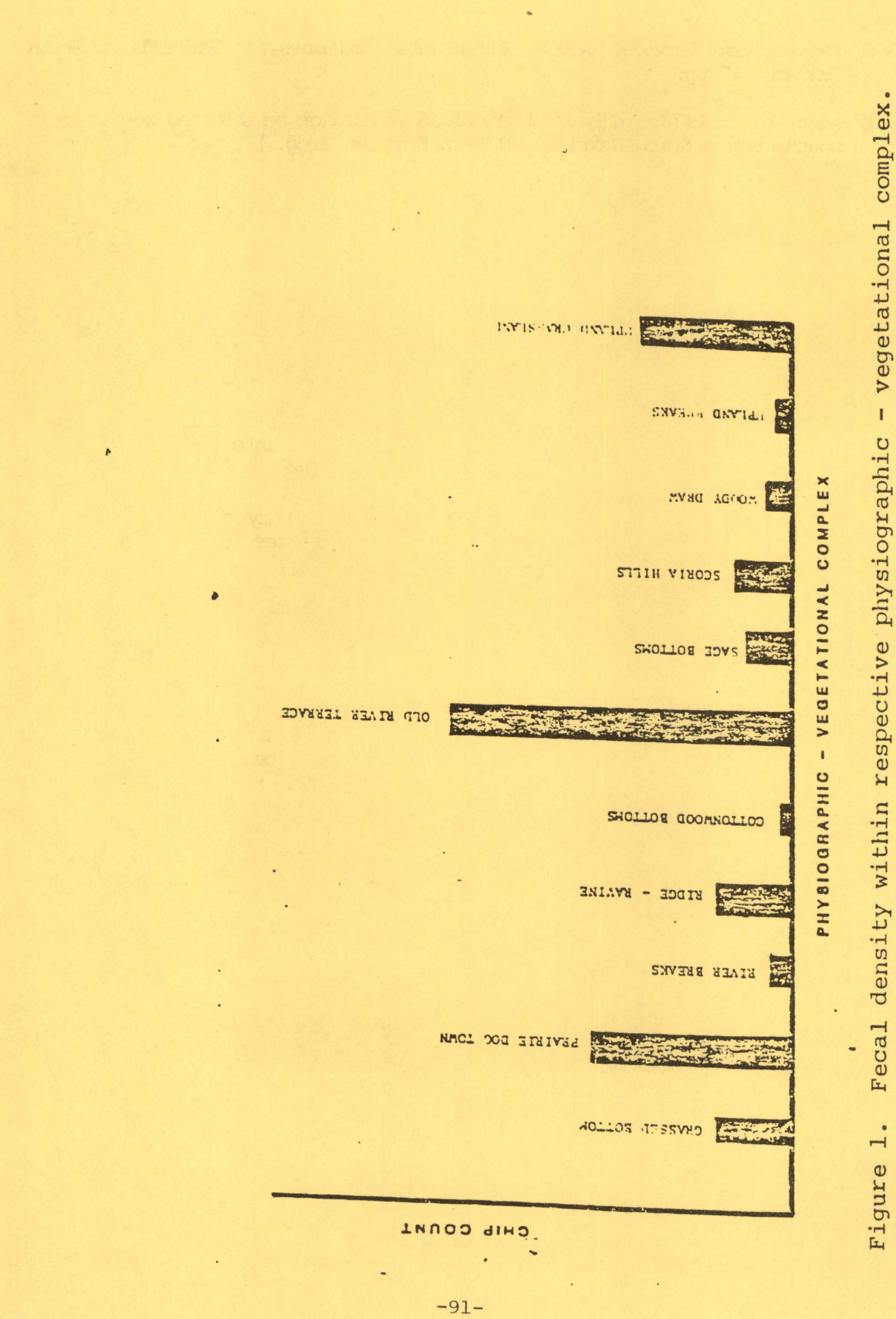


Soil conservation Service. N.D.A. Range site guidelines for Badlands of North Dakota. $47 \mathrm{pp}$.

Whitmann, W. C. 1978. Analysis of grassland vegetation on selected key areas in southwestern North Dakota. ND Reg. Environ. Prog. 172 pp. 